\title{
Vliv zatížení na stabilitu stoje u juniorské reprezentace moderního pětiboje
}

\section{Training workload influence to postural stability of junior national team pentathletes}

\author{
Sylvie Černá ${ }^{1}$, Lucia Malá ${ }^{1}$, Tomáš Malý ${ }^{1}$, Miroslav Čada² ${ }^{2}$ Jiř́i Nykodým ${ }^{2}$ \\ ${ }^{1}$ Fakulta tělesné výchovy a sportu Karlovy univerzity, Praha \\ ${ }^{2}$ Fakulta sportovních studií Masarykovy univerzity, Brno
}

\begin{abstract}
Abstrakt:
Tento př́spèvek se zabývá hodnocením vlivu sportovního zatižení na vybrané parametry posturální stability moderních pětibojařu (juniorů $n=7$, juniorek $n=5$ ), medailistů $z$ MS a ME juniorů. Měrení stability bylo provedeno na stabilometrické desce Footscan pred a po zátěži v simulovaných závodních podmínkách. Závěry vyplývající z experimentu: Vliv zátěže na stabilitu širokého stoje nelze za daných podminek potvrdit (na hladině významnosti $\alpha=0,05)$. Dosažený výsledek je zřejmě ovlivněn prodlevou mezi zátěží a měřením.
\end{abstract}

\begin{abstract}
:
The article evaluates influence of physical exertion on selected postural stability parameters of junior modern pentathletes (7 male athletes, 5 female athletes). Both medallists from juniors world or European championship. We have measured before and after exertion on stabilomethric desk Footscan. We have simulated racing conditions. Conclusions from the experiment are: we are not able to confirm influence of exertion on wide stand (from statistical point of view - on confidence level $\alpha=0,05$ ). We predicate the result is influenced by delay between exertion and measurement.
\end{abstract}

Keywords: $\quad$ postural stability; modern pentathlon; shooting posture; workload

Klícová slova: $\quad$ posturální stabilita; moderní pětiboj; střelecký postoj; zatížení

Tato studie vznikla za podpory VZ MSM 0021620864 a GACR 407/11/P7841514.

\section{ÚVOD}

Schopnost udržení rovnováhy lidského těla je základní motorickou schopností. Udržení rovnováhy u člověka zajištuje složitý regulační systém, který je výsledkem souhry analyzátorů, pomocí kterých vnímá člověk své okolí, a procesů centrální nervové soustavy, která integruje a zpracovává získané informace, a na základě tohoto umožňuje tvořit adekvátní svalové odpovědi (Fetz, 1987; Hatzitaki et al., 2002).

Funkci posturálního systému však ovlivňují i probíhající neurofyziologické změny, jako např. měnící se funkce vnitřních orgánů, psychické procesy atd. Je tedy zřejmé, že schopnost udržet stabilní postoj může být, zejména ve stádiu akcelerovaného vývoje, ovlivněna probíhajícími změnami i negativně (Nováková, 1997).

Z kinematického hlediska jsou pro střelecký výkon limitující somatomotorické charakteristiky závodníků. Z nich je, podle Pecníka a Kasy (2004), méně významný např́íklad somatotyp (nenalezli vztah mezi střeleckou výkonností a tělesnou konstitucí). Většina autorů se shoduje na výrazném vlivu koordinačních schopností. Fencl (1979) píše o nejpodstatnější pohybové schopnosti při střelbě - jemné motorice končetin a senzomotorické koordinaci, Nitzsche (1988) a Paugschová (2000) o značné míře vlivu úrovně koordinačních schopností (koordinační znaky - preciznost určená rovnovážnou, diferenciační a reakční schopností) a rychlosti a Brych (1985) o speciální rychlosti a obratnosti zajištující přesnost vykonávaných pohybů.

Lepers et al. (1997) zjistili, že po bežeckém zatížení dochází k výraznějšímu narušení stability stejně jako po jízdě na kole (Seliga et al., 1991) nebo chůzi (Derave et al., 2002). Navíc v př́ípadě běhu je tento vliv více znatelný při použití ergometru než při běhu v terénu (Hashiba, 1998). 
Nám dostupná literatura se sledované problematiky v souvislosti s moderním pětibojem dotýká pouze okrajově. Využití studií týkajících se biatlonistů a střelců specialistů je limitované specifikami jednotlivých sportů. U biatlonu spočívá podobnost ve střelbě při zátěži. U střelců specialistů hraje roli především fakt, že střelba probíhá v klidu, a že pistolových disciplín je několik s dalšími odlišnostmi od moderního pětiboje.

Vzhledem k tomu, že od 1.1.2009 došlo ke změně pravidel, hraje v případě moderního pětiboje nezanedbatelnou roli kromě výše uvedených faktorů také fakt, že samotná střelba je prováděna mezi úseky se značným fyzickým zatížením.

Přesnost střelby ve stoje bude tedy významně ovlivněna běžeckou částí, ve smyslu možného snížení posturální kontroly po zatížení. Na negativní vliv fyzického zatížení na stabilitu stoje poukazuje několik literárních zdrojů (Čech et al., 2010; Derave et al., 2002; Hoffman et al., 1992; Groslambert et al., 1998; Nardone et al., 1998; Tarantola et al., 1997). Někteří autoři prokazují zhoršení výkonu po zatížení, jiní poukazují jenom na nevýznamný rozdíl v indikátorech stability po zatížení ve srovnání se stabilitou v klidu. Našim cílem bylo ověřit vliv běžeckého zatížení na posturální stabilitu u pětibojařu elitní úrovně.

\section{METODIKA}

Výzkumný soubor tvořili junioři $(n=7)$ a juniorky $(n=5)$ z TJ Dukla Praha moderní pětiboj. Všichni probandi patří do širšího reprezentačního výběru. Základní antropometrické údaje jsou uvedeny v Tab.1. (metodika pro získání množství tělesného tuku - BIA 2000M). Probandi se v čase měření věnovali modernímu pětiboji 3-7 let. Většina se pravidelně zúčastňuje ME a MS v dané kategorii s medailovými úspěchy. Největší úspěchy získali v soutěži družstev a štafet (stříbro na ME juniorů 2009 a bronz na MS dorostu 2008 ve štafetách). Týdenní tréninkový objem pětibojařů byl 18-20 hodin.

Měření stability bylo provedeno na tlakové desce FOOTSCAN (RSscan International, Belgie), při snímací frekvenci $33 \mathrm{~Hz}$. Deska snímá pomocí tlakových senzorů tlakové působení dotekových částí těla (plosek chodidla) a následně je vyhodnocuje jako střed tlakového působení dotekových částí - centrum tlakového působení (COP - Centre of Pressure). Pro testování jsme zvolili dva 30sekundové testy širokého stoje, tzn. postoj v šíri ramen $\mathrm{s}$ chodidly rovnoběžně vedle sebe. 30 sekund je obvykle používáno při testování sportovců i běžné populace. S ohledem na to byl také volen typ postoje. Upřednostnili jsme základní postavení pro jeho porovnatelnost. Šířka postavení byla vymezena šířkou ramen (akromiální vzdálenost), kdy jsme antropometrem přenesli odměřenou vzdálenost na plochu tlakové desky a proband zaujal příslušné postavení (široká báze), přičemž vzdálenost vnějších stran chodidel korespondovala se šiŕkou ramen sportovce.

První test byl proveden se zrakovou kontrolou a druhý bez zrakové kontroly, přičemž test bez zrakové kontroly byl pouze doplňkový. Testování probíhalo před i po zatížení simulujícím závodní podmínky kombinované disciplíny (běh+střelba) v laboratorním prostředí. Zatěžování spočívalo v běhu na běhátku, kde každý proband absolvoval zatížení na anaerobním prahu (3x1 km s pauzou na střelbu 30-50 s). Samotné testování proběhlo 5 minut po absolvované zátěži kvưli odfiltrování vlivu zvýšené srdeční frekvence (např. $\mathrm{TF}_{\mathrm{anp}}$ se může pro jednotlivé probandy výrazně lišit) a akcentování možného vlivu svalové únavy a úbytku energetických rezerv. Intenzita zatížení byla pro každého probanda stanovena na základě individuálních výsledkủ předešlých funkčních zátěžových testů na běhátku. Pro nás byly důležité výsledky testů stability před a po zátěži. Další výsledky získané při měření (stabilita při střelbě) nejsou součástí tohoto článku.

Jako určující veličinu jsme použili celkovou dráhu centra tlakového působení TTW (Total Travel Way). Z dalších indikátorů projevu stability jsme sledovali rychlost COP a průměrnou délku trajektorie COP na jednotku snímací frekvence.

Stabilometrické vyšetření proběhlo za standardních podmínek podle Kapteyna (Kapteyn et al., 1983).

Pro zpracování výzkumných údajů jsme použili aritmetický průměr (charakteristika polohy) a směrodatnou odchylku (charakteristika variability).

K vyhodnocení naměřených výsledků jsme použili t-test. Testovali jsme platnost nulové hypotézy „TTW před zátěží se rovná TTW po zátěži“ oproti alternativě „TTW před zátěží je menší než TTW po zá- 
těži“. Normalita rozložení sledovaných údajů byla ověřovaná pomocí Shapiro-Wilkova testu. Rovnost rozptylů při nepárovém testu byla ověřovaná pomocí Levenova testu.

Riziko posouzení rozhodnutí o zamítnutí platnosti nulové hypotézy bylo stanoveno na p<0,05.

Tabulka 1. Základní antropometrické parametry juniorů a juniorek: průměr (směrodatná odchylka)

\begin{tabular}{|l|c|c|}
\hline \multicolumn{3}{|c|}{ Základní antropometrické parametry } \\
\hline & $\begin{array}{c}\text { Junioři } \\
(\mathrm{n}=7)\end{array}$ & $\begin{array}{c}\text { Juniorky } \\
(\mathrm{n}=5)\end{array}$ \\
\hline VĚK (roky) & $\begin{array}{c}18,2 \\
(1,17)\end{array}$ & $\begin{array}{c}19 \\
(1,67)\end{array}$ \\
\hline TV $(\mathrm{cm})$ & 186,3 & 167,2 \\
& $(7,03)$ & $(5,63)$ \\
\hline TH $(\mathrm{kg})$ & 70,9 & 59,0 \\
& $(4,26)$ & $(6,31)$ \\
\hline FAT \% & 8,2 & 12,3 \\
& $(0,93)$ & $(1,70)$ \\
\hline BMI $\left(\mathrm{kg} / \mathrm{m}^{2}\right)$ & 20,5 & 21,1 \\
& $(0,54)$ & $(1,85)$ \\
\hline
\end{tabular}

Legenda: TV - tělesná výška, TH - tělesná hmotnost, FAT - tuková hmota, BMI - Body Mass Index

\section{VÝSLEDKY}

Vyhodnocení zvolených parametrů širokého stoje se zrakovou kontrolou a bez ní je v tabulkách 2 a 3. Z výsledků vidíme, že průměry TTW sledované před a po zátěži se liší o $32 \mathrm{~mm}$. S přihlédnutím k počtu měření a směrodatným odchylkám ovšem $\mathrm{z}$ hlediska matematické statistiky nemáme dostatečnou evidenci k zamítnutí nulové hypotézy o rovnosti průměrů TTW ( $>00,05)$. Nebyl prokázán statisticky významný rozdíl mezi průměry skupin v rychlosti pohybu $\mathrm{COP}$, a to jak při zrakové kontrole, tak i bez ní $(\mathrm{p}>0,05)$. Průměrný posun COP na jednotku snímací frekvence se také neprokázal jako signifikantní $(\mathrm{p}>0,05)$. Porovnání průměrů celkové dráhy (TTW), průměrné rychlosti a průměrné dráhy COP mezi juniory a juniorkami prokázalo signifikatní rozdíl průměrů skupin při vstupním měření se zrakovou kontrolou $(\mathrm{p}<0.05)($ Obr.1).

Tabulka 2 Celková dráha COP: průměr a směrodatná odchylka rozdělená podle pohlaví, zrakové kontroly a zatížení

\begin{tabular}{|c|c|c|c|c|}
\hline \multicolumn{5}{|c|}{ Celková dráha - TTW (mm) } \\
\hline \multirow{2}{*}{\multicolumn{2}{|c|}{ Širký stoj }} & Junioři (n = 7) & Juniorky $(\mathrm{n}=5)$ & \multirow{3}{*}{$\begin{array}{c}\text { Celkem } \\
378,02 \pm 53,63\end{array}$} \\
\hline & & TTW & TTW & \\
\hline \multirow{2}{*}{ 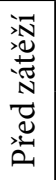 } & Se zrakovou kontrolou & $406,39 \pm 51,893$ & $338,31 \pm 22,178$ & \\
\hline & Bez zrakové kontroly & $409,44 \pm 57,669$ & $373,91 \pm 47,228$ & $394,63 \pm 54,40$ \\
\hline \multirow{2}{*}{ 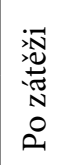 } & Se zrakovou kontrolou & $388,38 \pm 69,011$ & $405,66 \pm 55,142$ & $395,58 \pm 61,50$ \\
\hline & Bez zrakové kontroly & $427,40 \pm 76,869$ & $385,21 \pm 54,545$ & $409,82 \pm 69,11$ \\
\hline
\end{tabular}


Tabulka 3 Průměrná rychlost a trajektorie COP: průměr rozdělen podle pohlaví, zrakové kontroly a zátěže

\begin{tabular}{|c|c|c|c|c|c|}
\hline \multicolumn{6}{|c|}{ Absolutní rychlost $(\mathrm{mm} / \mathrm{s})$ a trajektorie $(\mathrm{mm})$ - průměry } \\
\hline \multirow{2}{*}{\multicolumn{2}{|c|}{ Široký stoj }} & \multicolumn{2}{|c|}{ Junioři $(\mathrm{n}=7)$} & \multicolumn{2}{|c|}{ Juniorky $(\mathrm{n}=5)$} \\
\hline & & \multirow{2}{*}{$\begin{array}{c}\text { Trajektorie } \\
0,41\end{array}$} & \multirow{2}{*}{$\begin{array}{c}\begin{array}{c}\text { Průměrná } \\
\text { rychlost }\end{array} \\
12,19\end{array}$} & \multirow{2}{*}{$\begin{array}{c}\text { Trajektorie } \\
0,34\end{array}$} & \multirow{2}{*}{$\begin{array}{c}\begin{array}{c}\text { Průměrná } \\
\text { rychlost }\end{array} \\
10,15\end{array}$} \\
\hline 滦 & Se zrakovou kontrolou & & & & \\
\hline 芠 & Bez zrakové kontroly & 0,41 & 12,28 & 0,37 & 11,22 \\
\hline \multirow{2}{*}{ 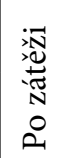 } & Se zrakovou kontrolou & 0,39 & 11,65 & 0,41 & 12,17 \\
\hline & Bez zrakové kontroly & 0,43 & 12,82 & 0,39 & 11,56 \\
\hline
\end{tabular}

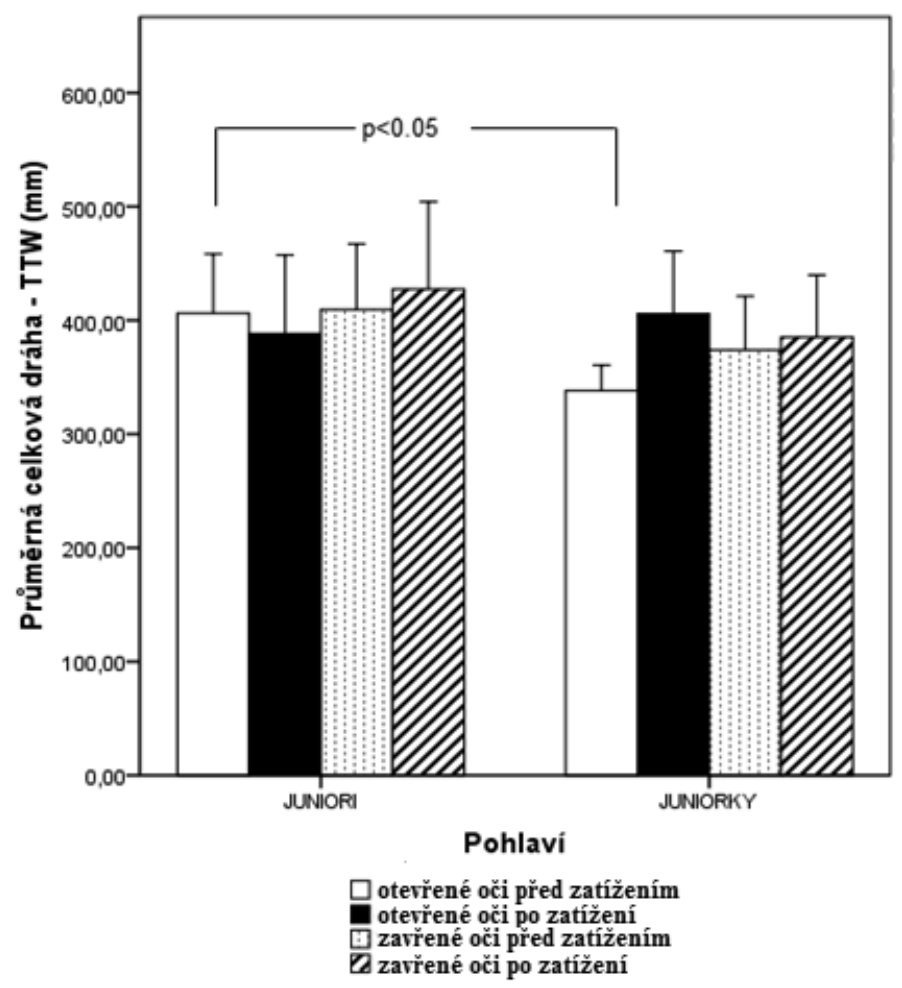

Obrázek 1 Změny celkové dráhy (TTW) u obou testů a skupin

\section{DISKUZE}

Individuální výstupy stabilometrického vyšetření před i po zátížení potvrdily horší hodnoty jednotlivých indikátorů stability ve shodě s dostupnou literaturou pouze u juniorek při testu se zrakovou kontrolou (Derave et al., 2002; Niinimaa \& McAvoy, 1983). Tento výsledek vysvětlujeme nižším relativním zatížením juniorů. Pro dosažení signifikantního rozdílu u juniorů bychom museli volit o něco vyšší relativní úroveň zatížení než u juniorek. Přestože jsme přímo nesledovali vliv zátěže při ostré střelbě pětibojařů, ani při její simulaci, simulova- 
li jsme samotný typ zatížení blízký soutěžním podmínkám $(3 x 1 \mathrm{~km})$. Nemůžeme tvrdit, že námi aplikovaná zátěž způsobila zhoršení sledovaných indikátorů stability (TTW, rychlost, trajektorie) po celkovém zatížení ve srovnání se základním stabilometrickým měřením v klidových podmínkách (p>0.05). Důvodem může být časový odstup po zátěži, stejně jako zvolená pozice (základní stabilometrické vyšetření). Stoj s rozšířenou základnou, při níž je proband stabilnější (Vařeka, 2002; Véle 1997), je i při odnětí zrakové kontroly pro většinu trénovaných jedinců jednoduchou pozicí ( $16 \%$ vyšší hodnoty TTW u juniorů, $12 \%$ vyšší hodnoty TTW u juniorek), a sportovci tedy nevykazují zvýšené hodnoty indikátorů stability bez ztížených podmínek (stoj na molitanu, stoj na jedné noze, jiné specifické testy). Samozřejmě, zvýšené hodnoty by se odvíjely podle stupně zátěže a stereotypu střeleckého postoje (Čech et al., 2010; Hoffman et al., 1992; Groslambert et al., 1999), protože samotná střelba se odehrává ještě za zvýšené srdeční frekvence, zvýšené ventilace a zvýšené stimulace CNS (Grosslambert et al., 1998; Klusiewicz, 2000). Stejně velkou roli bude hrát jak při základním stabilometrickém vyšetření, tak i při samotné střelbě po zátěži trénovanost sledovaných probandů, vykazujících vyšší úroveň stability ve srovnání $s$ běžnou populací. Při zohlednění trénovanosti je vždy třeba vycházet $z$ požadavku pro výkon v konkrétním sportu, $\mathrm{v}$ němž je potřeba provádět střelecké položky v co možná nejkratším čase při nejvyšší možné intenzitě zatížení bez snížení úspěšnosti střelby (Higginson, 2002). Podle Zemkové et al. (2004) každý námi zaznamenaný indikátor základního stabilometrického vyšetření mohl být ovlivněn i dalšími fyziologickými faktory (tělesná výška, tělesná hmotnost, pohlaví, věk, fyziologické asymetrie). Velmi významnou roli při stabilometrickém vyšetření mohla sehrát také psychika, resp. soustředění, které se jeví u juniorek výraznější. Z důvodů specifického složení testovací skupiny (juniorská reprezentace $\mathrm{v}$ moderním pětiboji - nejedná se tedy o náhodnou populaci) a při absenci norem pro stabilometrické vyšetření nelze vyvodit zevšeobecňující výsledky, ani věcně interpretovat jednotlivé posuny $\mathrm{v} \mathrm{mm}$ při indikátorech stability. Zpracování získaných dat $\mathrm{s}$ návazností na přesnost střelby po jednotlivých stupních zatížení při př́ípadném zohlednění dalších působících faktorů (Grimstone \& Hodges, 2003; Kantor et al., 2001; Mets et al., 2007) nám poskytne více informací. Těmito faktory mohou být např́íklad doba mezi zatížením a měřením stability nebo individuální míra zatížení a typ zatížení.

\section{ZÁVĚR}

Při finálním zhodnocení výsledků experimentu můžeme konstatovat, že rozdíly v posturální stabilitě dané běžeckým zatížením se za daných podmínek nepodařilo prokázat. Dủvodem může být specifická testovací skupina (vysoká trénovanost reprezentantů) nebo dlouhá prodleva mezi zatížením a měřením posturální stability.

\section{LITERATURA}

BRYCH, J. Sportovní střelba: Metodika výcviku ve střelbě puškou. Praha: Svazarm, 1985.

ČECH, P., MALÝ, T., MALÁ, L., PAUČÍR, L. Zmeny vybraných indikátorov statickej rovnováhy biatlonistov vplyvom špecifického zaṫǎenia. Česká kinantropologie, 2010, č. 1.

DERAVE, W., TOMBEUX, N., COTTYN, J., PANNIER, J. L. \& DECLERCQ, D. Treadmill exercise negatively affects visual contribution to static postural stability. International Journal of Sports Medicine, 2002, roč. 23, č.1, s. 44-49.

FENCL, S. Jednotný tréninkový systém SZBZ a DZBZ. Praha: Svazarm, 1979.

FETZ, F. Senzomotorisches Gleichgewicht im Sport. Wien: Ostereichisches Bundesverlag, 1987.

GITANANDA, S. DR. Jóga krok za krokem. Olomouc. Dobra a Fontana, 1999.

ISBN 80-861 79-38-9.

GRIMSTONE, S. K. \& HODGES, P. W. Impaired postural compensation for respiration in people with recurrent low back pain. Exp Brain Res, 2003, roč. 15, č. 2, s. 218-224.

GROSLAMBERT, A., GRAPPE, F., CANDAU, R. \& ROUILLON J. D. Cardio-ventilatory responses in biathlon standing shooting. Science \& Sports, 1998, roč. 13, č. 3, s. 135-137. 
GROSLAMBERT, A, CANDAU, R, HOFFMAN, M. D, BARDY, B \& ROUILLON, J. D. Validation of simple tests of biathlon shooting ability. International Journal of Sports Medicine, 1999, roč. 20, č. 3, s. 179-182.

HASHIBA, M. Transient change in standing posture after linear treadmill locomotion. Japan Journal of Physiology,1998, č. 6, s. 245-252.

HATZIKAZI V., ZISI V., KOLLIAS I., KIOUMOURTOZOGLOU E. Perceptual-Motor Contributions to Static and Dynamic Balance Control in Children. Journal of Motor Behavior, 2002, roč. 34, č. 2, s. 161-170. HIGGINSON, B. K., HEIL, D. P. \& CONANT, S. B. Effect of exercise intensity on shooting performance in elite-level summer biathletes. Medicine \& Science in Sports \& Exercise, 2002, roč. 34, č. 5, s. S26.

HOFFMAN, M. D., GILSON, P. M., WESTENBURG, T. M. \& SPENCER, W. A. Biathlon shooting performance after exercise of different intensities. International Journal of Sport Medicine, 1992, roč. 13, č. 3, s. 270-273.

KANTOR, E., POUPARD, L., LE BOZEC, S. \& BOUISSET, S. Does body stability depend on postural chain mobility or stability area? Neurosci Lett, 2001, č. 308, s. 128-132.

KLUSIEWICZ, A. Fizjologiczna charakterystyka wysiłku startowego w biathlonie. Sport wyczynowy, 2002, roč. 11, č. 12, s. 11-21.

KAPTEYN T.S.; BLES W.; NJIOKIKTJIEN CH. J.; KODDE L.; MASSEN C.H.; MOL J.M.F. Standardization in Platform Stabilometry being a Part of Posturography. Agressologie, 1983, roč. 24, č. 7, s. 321-326.

LEPERS, R.; BIGARD, A. X.; DIARD, J. P.; GOUTEYRON, J. F.; GUEZENNEC, CH., J. Posture control after prolonged exercise. European journal appl Physiol Occup Physiol, 1997, č. 76, s. 55-61.

METS, T.; KONTTINEN, N.; LYYTINEN, H. Shot placement within cardiac cycle in junior elite rifle shooters. Psychology of Sport and Exercise, 2007, č. 8, s. 169-177.

NARDONE, A.; TARANTOLA, J.; GIORDANO, A.; SCHIEPPATI, M. Fatigue effects on body balance. Electroencephalography and Clinical Neurophysiology, 1997, č. 105, s. 309-320.

NIINIMAA, V. ; MCAVOY, A. Influence of exercise on body sway in the standing rifle shooting position. Canadian journal of applied sport sciences, 1983, roč. 8, č. 1, s. 30-33.

NITZSCHE, K. Biathlon, technik, training, taktik. Berlin: Sportverlag, 1988.

NOVÁKOVÁ H. Využití externích systémů ve sportovní př́pravě mládeže a dospělých sportovců. Praha: Resortní výzkum MŠMT (nepublikováno), 1997.

PAUGSCHOVÁ B. Teória a metodika športovej pripravy v biatlonu. Banská Bystrica: UMB, 2002.

PECNÍK V.; KASA J. Vztah tělesných a pohybových predpokladov k športovej výkonnosti vrcholových strelcov. Sborník z MVK Sport a kvalita života. Brno: Masarykova univerzita, 2004.

SELIGA, R.; BHATTACHARYA, A.; SUCCOP, P.; WICSTROM, R.; SMITH, D.; WILLEKE, K. Effect of work load and respirator wear on postural stability, heart rate, and perceived exertion. Am Ind Hyg Assoc J, 1991, č. 52, s. 417-422

TARANTOLA, J.; NARDONE, A.; TACCHINI, E.; CHIEPPATI, M. Human stance stability improves with the repetition of the task: effect of foot position and visual condition. Neuroscience letters, 1997, č. 2, s. 75-78.

VA ŘEKA, I. Posturální stabilita II. část. Řizení, zajištění, vývoj, vyšetření.

Rehabilitace a fyzikální lékařství, 2002, č. 4, 122-129.

VÉLE, F. Kineziologie pro klinickou praxi. Praha: Grada Publishing, 1997, s. 271.

ZEMKOVÁ, E.; HAMAR, D. Stabibilita postoja a telesné zataženie. Abstrakty z III. Vysegradskeho kongresu telovýchovného lekárstva,2006.

ZEMKOVÁ, E.; HAMAR, D.; BÖHMEROVÁ, L. Reliabilita rýchlosti pohybu tažiska pri posudzovaní stability postoja $\mathrm{v}$ dynamických podmienkach [Reliability of velocity of centre of gravity during evaluation postural stability in dynamic conditions]. Phys Educ Sport, 2004, roč. 14, č. 3-4. 